\title{
DESIGN OF INTEGRATED BIOFUEL SUPPLY CHAIN WITH STRATEGIC, ECONOMIC AND ENVIRONMENTAL CRITERIA
}

\author{
Yunzile Dzhelil, Evgeniy Ganev, Dragomir Dobrudzhaliev \\ Bulgarian Academy of Sciences, Institute of Chemical Engineering \\ 1113 Sofia, Bulgaria \\ phones: +359894301679, +359894460421, +359889099038 \\ e-mail: unzile_20@abv.bg, evgeniy_ganev@abv.bg,dragodob@yahoo.com
}

\begin{abstract}
The society today is facing important decisions on ways to reduce greenhouse gas emissions that result mostly of the transport sector and the operation of thermal-energy systems. These lead to global warming and continuously reduce of the ledge and raw materials for fossil fuels. The use of renewable sources for generate energy is one approach to solving these problems. Such appropriate conclusion is the use of biofuels. They represent energy alternative to fossil fuels that lead to reduce greenhouse gas emissions. The biofuels are produced from renewable sources that lead to increase energy security. The Directive 2003/30 / EC is for the promotion of biofuels. It aims by 2020 the use of biofuels to increase to 10\%. Design of optimal Biofuel Supply Chain cesures a competitive product on the market and achieve the objective of the Directive. Design of integrated biofuel Supply Chain on strategic, economic and environmental criteria leading to minimize the total cost of the chain and are seeking to have regulated environmental impacts throughout their life cycle. Depending on these criteria solve a set of optimal alternatives with corresponding strategic decisions. The presented work examines the stages of planning integrated SC strategic, economic and environmental criteria. Economic criteria determine the total annual costs. Environmental criteria determine the noxious atmospheric emissions over the entire life cycle. Integrated SC is planned for an extended time horizon.
\end{abstract}

Keywords: Biofuel, Supply Chain, Strategic, Economic and Environmental criteria.

\section{INTRODUCTION}

The continuous reduction of fossil fuels, climate change and decreasing energy security are the reasons for search new renewable energy. Biomass is a solution to our dependence on fossil fuels, since it can be used as raw material for biofuels. The use of eco-fuels instead of fossil fuels would reduce emissions of greenhouse gases; improve the ecological environment and quality of life; and lead to new jobs and bigger economic vitality in village areas.

Directive 2003/30 / EC was adopted on May 8, 2003 to promote the use of biofuels and other renewable fuels in transport, which should gradually enter into diesel and gasoline fuels in each Member State. It has recommendatory character; their share was increased $2 \%$ for $2005,5.75 \%$ for 2010 and $10 \%$ in 2020.

Cultivation of biomass for compliance with the aims of the Directive on one hand may require new processing land, which would lead to the eradication of trees and processing pastures. On the other hand it could lead to food shortages and increase the price in food products, as most of the raw materials are competitors with the food industry. The solution of these problems and the compliance with the Directive introduced by the EU is implemented by a design of Supply Chain (SC) on strategic, economic and environmental criteria. Biofuel SC includes a wide range of activities, i.e. the whole lifecycle chain. 


\section{AR'T'TE

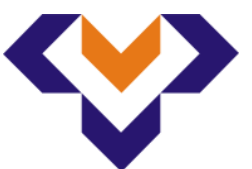 \\ Ipplied Researthes in Technics, Technologies and Bdurition \\ Journal of the Faculty of Technics and Technologies, Trakia University https://sites.google.com/a/trakia-uni.bg/artte/}

The life cycle of the chain examines the steps from the preparation of biomass, its transformation, the use of the resultant product to recycling and disposal [2]. Design and management of optimum integrated SC includes decisions on three hierarchical levels: strategic, tactical and operational decision.

The strategic decision is connected to the choice of production technology, bio- refinery location and configuration of the network. Tactical and operational decisions are related with production planning, selection of feedstock and warehouse storage and ways of pretreatment. lakovou $\mathrm{E}$ and others. [7]. give a detailed analysis of the three main hierarchical decisions.

There are many scientific works examine in different aspects the design and planning of traditional biofuels Supply chain such as the choice of feedstock $[4,5,11,13]$ location and power bio refinery [1,3,14], the choice of technology for the production [ 9.12] SC for biofuels in individual economic, social and environmental dimension. All these articles considered different stages of the production of biofuels and the design of the entire biofuel SC, but in separate criteria which are not solution for complex tasks related to the environment, economy and social society. The articles covering the three criteria are very few [10].

In this work are presented the stages of design an integrated biofuel SC on strategic, economic and environmental criteria.

\section{PROBLEM STATEMENT}

The problem described in this paper aims to present the stages of design SC for biofuels with minimizes chain costs, environmental impact and maximizing social criteria with appropriate compromises.

\subsection{Stages in design of biofuel Supply Chain}

The term SC is defined as a process for coordination between its constituent elements: suppliers (manufacturers of raw materials), manufacturers/producers, warehouses, distributors and consumers [12, 14] (Fig. 1).

The design of SC begins with determination of the type of feedstock and the location for its cultivation (import or domestic production) regard been had to the scarcity of farmland and shortage of food and food products. It should be taken into account that some types of feedstock can be cultivated on alkali soil and soil unsuitable for cultivation of crops for the food industry.

The next stage must solve problems such as collection and transportation to warehouses for storage of biomass and onward transportation to biorefineries, by making a special coordination system that provides the best opportunity between regions.

The most important stage of the production of biofuel is making choice of location and technology for its production. The optimum capacity of biorefineries should also be taken into account. Capacities should be provided to meet market requirements and EU Directive.

The final stage of production of biofuels is the choice of type transport and route of transporting to facilities for mixing biofuels with fossil fuels. Their locations should be identified as derived biofuels in pure form can only be used in hybrid / special vehicles, which requires mixing with petroleum fuels for mass use by ordinary internal combustion engine. They can be mixed with a fossil fuel in various ratios, for example, a mixture of $85 \%$ ethanol and $15 \%$ gasoline is referred to as E85 and most popular diesel blend is B30 - 30\% biodiesel and $70 \%$ petro-diesel. 


\section{IRTTIC Y $Y$ P}
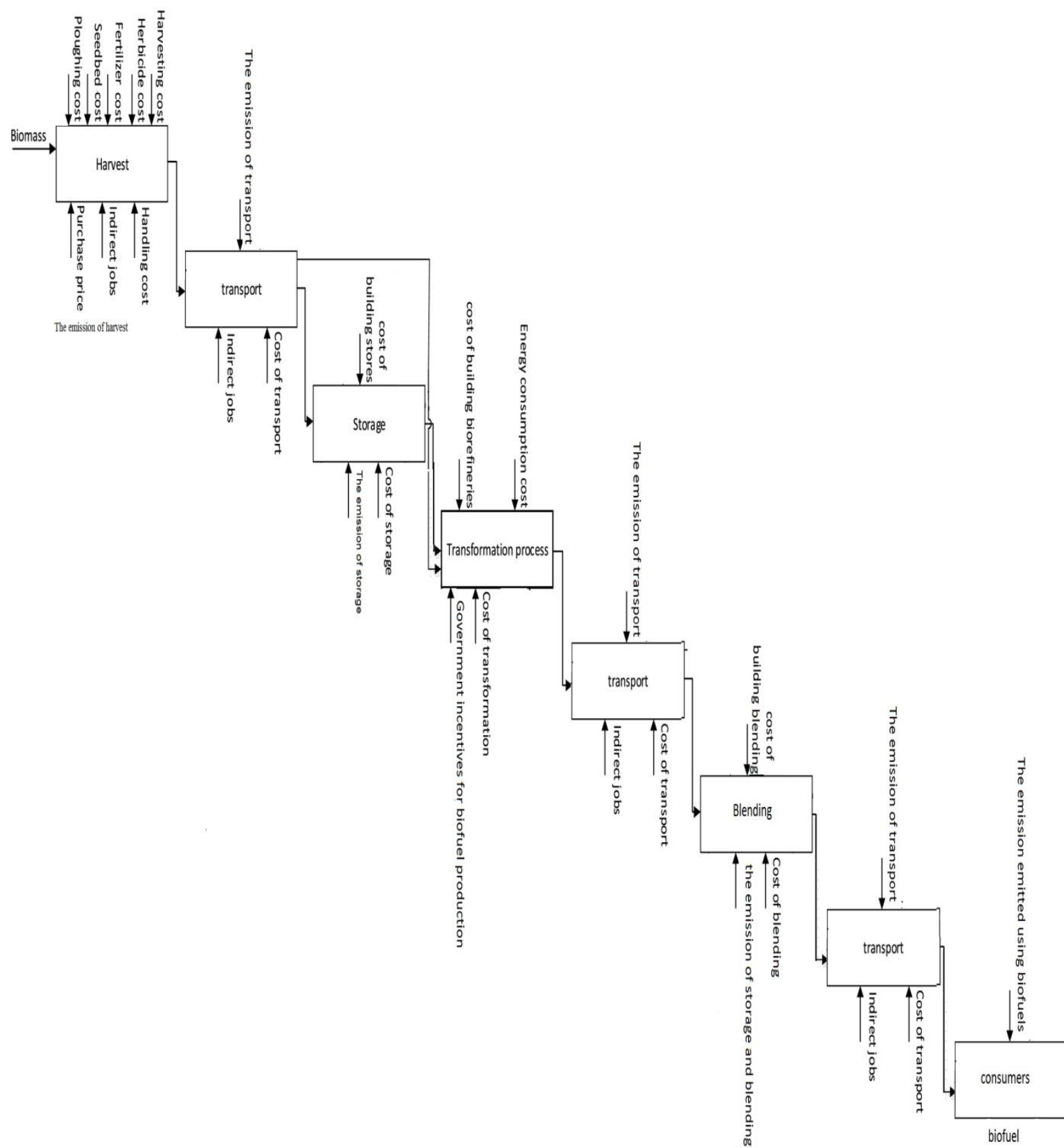

SUPPLIERS

TRANSPORT

WAREHOUSES

PRODUCERS

TRANSPORT

BLENDING

DISTRIBUTORS

CONSUMERS

Figure 1. Supply Chain for biofuel production

IRTITE Vol. 5, No. 1, 2017 ISSN 1314-8788 (print), ISSN 1314-8796 (online), doi: 10.15547/artte.2017.01.004 


\section{IRTIIE \\ Ipplied Researrches in Technics, Technologies and Educiation \\ Journal of the Faculty of Technics and Technologies, Trakia University https://sites.google.com/a/trakia-uni.bg/artte/}

Supply chain design needs to be related with three main criteria:

\section{Economic criteria}

This criterion is connected to the increase of profits by reducing the total annual cost, total annual capital expenditures, and management of long-term risks and promotes long-term competitive power.

The economic costs of SC include: costs of handling, transportation and storage of biomass, transport costs of biomass from store to a biorefinery, the cost of its transformation, transport cost to facilities in blending and to transporting of finished product to warehouses for storage. The total amount of capital expenditure is equal to the total cost of installing biorefineries and collection facilities minus government stimulus to build biofuel production capacities.

The economic criterion is calculated by:

$$
G r=K r+K b h+K b t+K b i+K b d+K p+K p i+K p t-K p c
$$

Where,

Kr-annual capital costs;

$K b h$ - total cost of harvest, $(€ / \mathrm{kg})$;

$K b t$ - total transport cost of biomass, $(€ / \mathrm{kg})$;

$K b i-$ storage costs of the biomass, $(€ / \mathrm{kg})$;

$K b d$ - handling costs of the biomass, $(€ / \mathrm{kg})$;

$K p$ - production costs, $(€ / \mathrm{kg})$;

$K p i-$ cost of fuel storage, $(€ / \mathrm{l})$;

$K p t-$ general transportation costs of biofuel, $(€ / \mathrm{I})$;

$K p c-$ Government incentives for biofuel production, (€/I).

\section{Environmental criteria}

Its aim is to control and reduce the amount of energy and resources by using larger amounts of renewable and less polluting energy atmosphere; increasing the amount of recycling and reducing the amount of carbon; increasing energy efficiency.

In environmental criteria are calculated separately emissions in the whole lifecycle circuit because as with the cultivation and processing of biomass and in the receipt and distribution of biofuels are using raw materials that pollute the environment.

The ecological criterion aims to minimize the total annual emissions of greenhouse gases (GHG).

The three main greenhouse gases emitted by a SC are methane $\left(\mathrm{CH}_{4}\right)$, nitrous oxide $\left(\mathrm{N}_{2} \mathrm{O}\right)$ and carbon dioxide $\left(\mathrm{CO}_{2}\right)$. Total $\mathrm{GHG}$ emissions are measured from the point of view of $\mathrm{CO}_{2}$ - equivalent emissions ( $\mathrm{CO}_{2}$-eq). Greenhouse gases are $1 \mathrm{~g} \mathrm{CH}_{4}=25 \mathrm{~g} \mathrm{CO}_{2}$-eq. and $1 \mathrm{~g} \mathrm{~N}_{2} \mathrm{O}$ $=298 \mathrm{~g} \mathrm{CO}_{2}$-eq according to the latest assessment report of the Intergovernmental Panel on Climate Change [8].

The calculation of the ecological criteria and the minimizing of $\mathrm{CO}_{2}$ emissions are given by the following equation

$$
T E=E b h+E b d+E b i+E b t+E p+E p t+E p m+E B c a r+E G c a r
$$

Where,

Ebh - The emission of cultivating and obtaining feedstocks, ( $\mathrm{kg} \mathrm{CO}$-eq. / $\mathrm{kg}$ biomass);

$\mathrm{Ebd}$ - The emission of drying unit amount of biomass, ( $\mathrm{kg} \mathrm{CO}_{2}$-eq. / $\mathrm{kg}$ biomass);

IRIIIE Vol. 5, No. 1, 2017 ISSN 1314-8788 (print), ISSN 1314-8796 (online), doi: 10.15547/artte.2017.01.004 


\section{IRTTIE

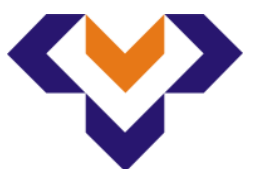 \\ Ipplied Resseirlohes in Technics, Technologies and Bductation \\ Journal of the Faculty of Technics and Technologies, Trakia University https://sites.google.com/a/trakia-uni.bg/artte/}

Ebi-The emission of storing unit amount of biomass, ( $\mathrm{kg} \mathrm{CO}_{2}$-eq. $/ \mathrm{kg}$ biomass);

Ebt - The emission of transporting unit amount biomass, ( $\mathrm{kg} \mathrm{CO}$-eq. / $\mathrm{kg}$ biomass);

$\mathrm{Ep} \mathrm{-} \mathrm{The} \mathrm{emission} \mathrm{of} \mathrm{producing} \mathrm{unit} \mathrm{amount} \mathrm{biofuel} \mathrm{from} \mathrm{biomass,}(\mathrm{kg} \mathrm{CO}$-eq. $/ \mathrm{kg}$ biomass);

Ept-The emission of transporting unit amount biofuel, $\left(\mathrm{kg} \mathrm{CO}_{2}\right.$-eq./ /);

Epm - The emission of blending and distributing unit amount of biofuel, ( $\mathrm{kg} \mathrm{CO} \mathrm{CO}_{2}$-eq. / gallon);

EBcar - The emission emitted using biofuels in transport, $\left(\mathrm{kg} \mathrm{CO}_{2}\right.$-eq. / I.);

EGcar - The emission emitted using conventional fuels in transport, $\left(\mathrm{kg} \mathrm{CO} \mathrm{CO}_{2}-\mathrm{eq} / \mathrm{l}\right.$.).

\section{Strategic criterion}

The strategic criterion aims to calculate the increase of jobs in the regional economy during the project lifecycle. Here should be taken into account jobs created during both phases of the project in the construction and operational phases.

Construction phase includes jobs involved in building a biorefinery, storage facilities and blending of biofuel with conventional fuel.

In the operational phase includes jobs after release cycle biofuel production.

Biofuel Supply chain design on strategic, economic and environmental criteria provides a sustainable system for the chain, Figure 2.

Sustainable development is introduced by the Bruntland Commissions of the UN in 1987 [6] as SC complies with the needs of the present without compromising the ability of future generations in satisfying their needs. This requirement gives a balance between environmental, economic and strategic criteria.

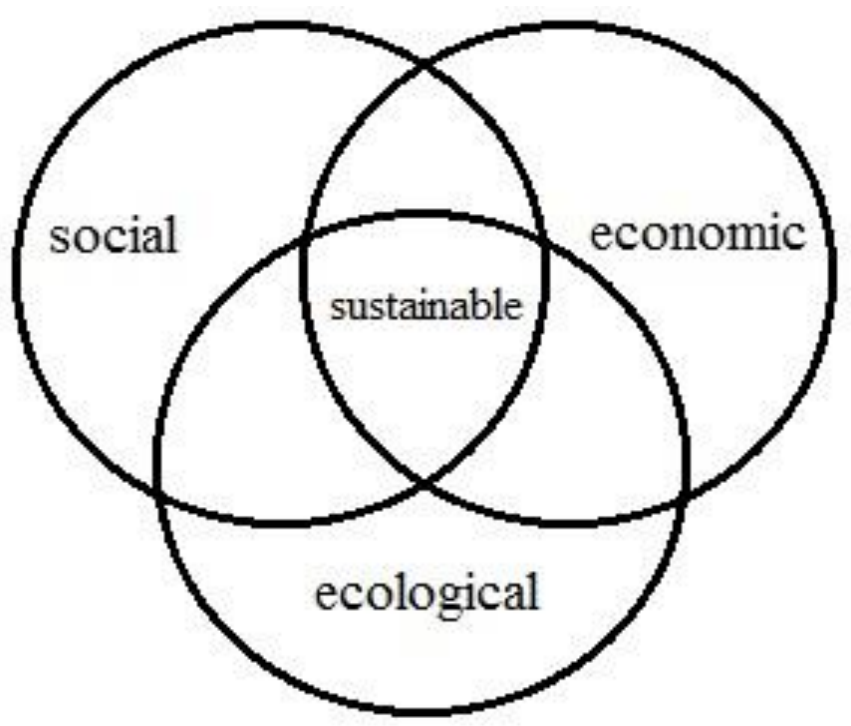

Figure 2 Sustainable Supply Chain

\section{CONCLUSIONS}

Biofuel production is expected to quickly develop during the next decades. We have developed an approach for Biofuel Supply Chain designing on economic, environmental and strategic criteria, taking into account the main characteristics of biofuels such as seasonality for supply of raw materials, geographic diversity and availability of biomass, other conversion technologies, recycling of by-products, distribution demand, and regional economic situation.

IRTIIE Vol. 5, No. 1, 2017 ISSN 1314-8788 (print), ISSN 1314-8796 (online), doi: 10.15547/artte.2017.01.004 


\section{ARTTIE $Y$}

Ipplied Resseirlohes in Technics, Technologies and Bductation

Journal of the Faculty of Technics and Technologies, Trakia University https://sites.google.com/a/trakia-uni.bg/artte/

Developed model allows the reduction of the minimum economic cost and the decrease of harmful emissions released in the chain by making the necessary compromises on all three criteria. The design of optimal Biofuel Supply Chain can solve a wide range of issues related to biofuels, because this area changes very fast (not just economic but also involving strategic decisions relating to domestic consumption or export the produced biofuelproducing region biomass, etc.).

\section{INFERENCES}

The following conclusions must be made:

1. When designing each of the proceedings for biofuels should provide the amount consumed fossil fuels needed for production itself and of transporting the raw materials and production. It has to take into account the total amount of carbon emissions from the production; forwarding and exploitation of the fuel product, which should not exceed the amount of carbon emissions, assimilated by the plant predecessor of the feedstock used accumulating biomass.

2. Raw material needed for a particular biofuel production in most cases is also the feedstock for food and feed which directly or indirectly satisfy the needs of the population inhabiting the areas in which they are grown. Areas that will be cultivation of raw material for production should not compete with areas needed to feed the population in this area.

3. Biorefineries must be designed so that there is a sustainable balance, taking into account the uncertainties that would result from changes in currency exchange rates, oil fuel, feedstock for production, labor force majeure and others.

\section{REFERENCES}

[1] Bowling I, Ponce-Ortega J, El-Halwagi M. (2011) Facility location and supply chain optimization for a biorefinery. Ind Eng Chem Res 2011;50(10):6276-86.

[2] Commission, E, (2010). International Reference Life Cycle Data System (ILCD) Handbook. In: General Guide for Life Cycle Assessment e Detailed Guidance. Joint Research Centre e Institute for Environment and Sustainability, Luxembourg

[3] Dunnett A, Adjiman C, Shah N. (2008) A spatially explicit whole- system model of the lignocellulosic bioethanol supply chain: an assessment of decentralized processing potential. Biotechnol Biofuel 2008;1(1):1-17.

[4] Elia J, Baliban RC, Xiao X, Floudas C. (2011) Optimal energy supply network determination and life cycle analysis for hybrid coal, biomass, and natural gas to liquid (CBGTL) plants using carbon-based hydrogen production. Comput Chem Eng 2011;35(8):1399-430.

[5] Giarola S, Zamboni A, Bezzo F. (2011) Spatially explicit multi-objective optimization for design and planning of hybrid first and second generation biorefineries. Comput Chem Eng 2011;35(9):1782-97.

[6] http://www.channelingreality.com/Documents/Brundtland_Searchable.pdf

[7] lakovou E, Karagiannidis A, Vlachos D, Toka A, Malamakis A, (2010) Waste biomass to energy supply chain management: a critical synthesis. Waste Manage 2010; 30:186070.

[8] IPCC, Climate change 2007: Synthesis report (online). Available from: $<$ http://www.ipcc.ch/publications and data/publications ipcc fourth assessment report synthesis report.htm > Accessed July 2011

[9] Kim J, Realff M, Lee J, Whittaker C, Furtner L. (2011) Design of biomass processing network for biofuel production using an MILP model. Biomass Bioenergy 2011;35(2):853-71.

IRTIIE Vol. 5, No. 1, 2017 ISSN 1314-8788 (print), ISSN 1314-8796 (online), doi: 10.15547/artte.2017.01.004 


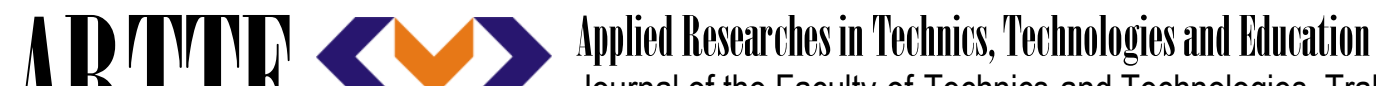 Journal of the Faculty of Technics and Technologies, Trakia University https://sites.google.com/a/trakia-uni.bg/artte/}

[10] Seuring S., Muller M., (2008), From a literature review to a conceptual framework for sustainable supply chain management, Journal of Cleaner Production 16 (2008) 16991710.

[11] Sokhansanj S, Kumar A, Turhollow A. (2006) Development and implementation of integrated biomass supply analysis and logistics model (IBSAL). Biomass Bioenergy 2006; 30(10):838-47.

[12] You F, Tao L, Graziani DJ, Snyder SW, (2012) Optimal design of sustainable cellulosic biofuel supply chains: multi objective optimization coupled with life cycle assessment and Input / output analysis. AIChE J 2012; 58(4):1157-80.

[13] You F, Wang B. (2011) Life cycle optimization of biomass-to-liquid supply chains with distributede centralized processing networks. Ind Eng Chem Res 2011;50(17):10102-27.

[14] Zamboni A, Shah N, Bezzo F., (2009) Spatially explicit static model for the strategic design of future bioethanol production systems. 1. Cost minimization. Energy Fuels 2009; 23(10):5121-33. 